\title{
Perencanaan LTE-A untuk Heterogeneous Network dengan Metode CADS4 di Grand Asia Afrika
}

\author{
YOGI ARIYANTO, HASANAH PUTRI*, ATIK NOVIANTI \\ Program Studi D3 Teknologi Telekomunikasi Telkom University \\ *Email: hasanahputri@tass.telkomuniversity.ac.id
}

Received 4 Februari 2021 | Revised 25 Februari 2021 | Accepted 16 April 2021

\begin{abstract}
ABSTRAK
Berdasarkan hasil pengukuran di Grand Asia Afrika (GAA) diketahui terdapat peningkatan kualitas jaringan setelah pemasangan unit COMBAT selama 7 hari. $R S R P \geq-95 \mathrm{dBm}$ sebelumnya sebesar 75,70\% menjadi 100\%, SINR $\geq 0 \mathrm{~dB}$ dari $53,58 \%$ menjadi $97,54 \%$, dan throughput $\geq 8$ Mbps sebelumnya sebesar 48,12\% menjadi $89,55 \%$. Untuk mempertahankan kualitas tersebut maka dibangunlah small cell. Perencanaan menerapkan metode inter-band carrier aggregation pada heterogen network LTE dengan skema CADS4 sebagai pengganti unit COMBAT. Tujuan perencanaan ini adalah extended throughput dan agar kualitas layanan pada beban trafik tinggi tetap baik. Macro cell sebagai Primary Cell (PCell) pada band-1 $2100 \mathrm{MHz}$ dan micro cell sebagai Secondary Cell (SCell) pada band-3 1800 MHz. Hasil perencanaan menunjukkan telah memenuhi standar RF Parameter LTE yaitu RSRP sebesar -92,65 dBm, SINR sebesar 16,55 dB, throughput sebesar 1,062 Mbps, dan user connected $97 \%$.
\end{abstract}

Kata kunci: LTE-A, heterogen network, CADS4, Great Asia Afrika Bandung

\begin{abstract}
Based on the report on the development of temporary sites in the tourist area of Great Asia Africa (GAA), it shows that the DRR rate is $>90 \%$ in the sectors leading to GAA. From the measurement, it is known that there is an increase in network quality after installing the COMBAT unit for 7 days. For RSRP $\geq-95 \mathrm{dBm}$, the previous amount was $75.70 \%$ to $100.00 \%$, for SINR $\geq 0 \mathrm{~dB}$ previously it was $53.58 \%$ to $97.54 \%$, and for throughput $\geq 8$ Mbps the previous was $48.12 \%$ to $89,55 \%$. To maintain the quality of the network, small cells were built to cover the GAA area. Planning to apply the inter-band carrier aggregation method to the heterogeneous LTE network with the CADS4 scheme to replace the COMBAT unit. The purpose of planning is to provide extended throughput and so that the service quality at high traffic loads remains good. The configuration used is a macro cell as a Primary Cell (PCell) in the band-1 $2100 \mathrm{MHz}$ and a micro cell as a Secondry Cell (SCell) in the $1800 \mathrm{MHz}$ band-3. The results of the planning meet the LTE parameter RF standards, RSRP of $-92.65 \mathrm{dBm}$, SINR of $16.55 \mathrm{~dB}$, throughput of $1.062 \mathrm{Mbps}$, and users connected to $97 \%$.
\end{abstract}

Keywords: LTE-A, heterogen network, CADS4, Great Asia Afrika Bandung 
Ariyanto, dkk

\section{PENDAHULUAN}

Pada momen libur baik akhir pekan maupun libur panjang seperti tahun baru dan hari raya, lonjakan trafik jaringan LTE terjadi di berbagai lokasi obyek wisata (Agustina, 2019). Salah satu operator seluler di Indonesia memprediksi pada musim liburan trafik data akan mengalami peningkatan 26,34\%. Prediksi tersebut didasari perilaku pelanggan yang cenderung menggunakan internet seperti aktivitas di media sosial, streaming video, atau streaming music. Untuk akses layanan berbasis streaming, diperkirakan akan terjadi kenaikan sebesar $51 \%$, dibandingkan periode sebelumnya dan tidak menutup kemungkinan akan meningkat pada tahun-tahun berikutnya (Faz, 2019). Optimalisasi elemen jaringan perlu dilakukan untuk menjaga persepsi pelanggan terhadap kualitas layanan yang diberikan selama periode tersebut. Maka dari itu provider dituntut untuk mengimbangi kapasitas jaringan untuk mengatasi lonjakan trafik dan menyediakan layanan ber-data rate tinggi khususnya di daerah obyek wisata yang dikategorikan sebagai lokasi Point of Interest (POI).

GAA merupakan salah satu obyek wisata baru yang terletak di Desa Gudang Kahuripan, Kecamatan Lembang, Kabupaten Bandung Barat. Saat periode pengamatan dari tanggal 19 Desember 2019 hingga 05 Januari 2020 pada sector leve/ tercatat persentase PRB tertinggi sebesar $98, \%$ dan total user connected tertinggi sebesar 537 . Dengan nilai PRB yang critical tersebut, meskipun banyak user masih bisa dilayani ada hal yang dikorbankan yaitu throughput per-user menurun. Untuk tetap menjaga user experience para pengunjung GAA akibat kapasitas site yang penuh, dibangun penambahan new site berupa unit compact mobile base station (COMBAT) yang sifatnya temporary untuk periode 30 Desember hingga 05 Januari 2020 dengan tujuan untuk menjaga kualitas layanan yang dirasakan oleh user yang terpusat di sektor 2 site Pasirwangi. Untuk menggantikan temporary site tersebut, akan dibangun site baru berupa site small cel/untuk mencakup area GAA. Untuk memaksimalkan kinerja jaringan, penambahan site small cell akan memanfaatkan fitur carrier aggregation yang diharapkan dapat meningkatkan throughput user di beberapa titik keramaian akibat dual connectivity yang didapatkan user dari kedua sel macro dan micro.

Pada penelitian (Wang, dkk, 2013), dijelaskan bahwa penggunaan inter-site carrier aggregation antara macro cell dan small cell menggunakan skema Carrier Aggregation Deployment Scenario 4 (CADS4) sehingga User Equipment (UE) dapat terhubung ke macro dan micro cell. Akibatnya extended throughput akan terjadi pada area hotspot karena aksesibilitas bandwidth lebih besar untuk hotspot area small cell. Dari hasil pengujian, peningkatan throughput bisa mencapai $70 \%$ dengan kondisi beban rendah karena bandwidth transmisi yang tersedia lebih besar namun akan menurun secara bertahap saat beban meningkat. Performansi terbaik hanya tercapai pada UE yang mendukung fitur Carrier Aggregation (CA) sedangkan untuk UE yang belum mendukung CA hanya akan tersambung ke salah satu macro cell atau small cel/ tergantung kekuatan sinyal (RSRP) dominan. Pada penelitian (Kusuma, Fadli, 2019) telah dilakukan perancangan jaringan LTE - Advanced inter-band carrier aggregation pada intra-site macro menggunakan skema CADS2 untuk meningkatkan performansi jaringan. Dari hasil simulasi skenario dengan dan tanpa CA, didapat persentase peningkatan parameter RSRP, SINR dan throughput masing-masing sebesar $9,12 \%, 35,54 \%$ dan 42,33\%. Dari ketiga parameter tersebut hanya dua paremeter yang mencapai target yaitu SINR yang mencapai target $70 \%>5 \mathrm{~dB}$ dengan nilai rata-rata sebesar $16,72 \mathrm{~dB}$ dan parameter throughput $70 \%>10.000 \mathrm{kbps}$ dengan nilai rata-rata throughput mencapai 27.526 kbps. Pada penelitian (Geraldine, 2019), dilakukan perancangan jaringan LTE - Advanced inter-band carrier aggregation pada intra-site macro menggunakan skema Carrier Aggregation Deployment Scenario 2 (CADS2) untuk memperbaiki performasi jaringan site existing dari sisi kapasitas user dan untuk memberikan tambahan throughput. Dari 
simulasi, hasil yang paling optimal diperoleh peningkatan parameter RSRP, SINR dan throughput masing-masing sebesar 97,33\%, 99,03\% dan 100\% diikuti penurunan persentase PRB sebesar 44,50\% dari kondisi awal sebesar $82,6 \%$. Sedangkan pada penelitian (Diansyah, 2019), dilakukan perancangan jaringan $L T E$ - Advanced Pro menggunakan tri-band carrier aggregation pada intra-site macro untuk memperbaiki performansi jaringan dari sisi kapasitas user dengan penggunaan spektrum yang lebih efisien. Dari hasil simulasi skenario dengan dan tanpa CA, pada kondisi traffic load yang sama, didapat persentase PRB sebelum sebesar $94,50 \%$ dan setelah sebesar 35,44\%. Pada penelitian (Mubarok, 2019) dilakukan penelitian dampak dari penerapan metode inter-band carrier aggregation pada jaringan $\angle T E$-Advanced. Hasil yang diperoleh adalah peningkatan throughput sebanyak 13 Mbps dan penggunaan spektrum yang lebih efisien. Pada penelitian (Putri, 2021) dilakukan perencanaan jaringan LTE_A dengan menerapkan metode CADS2. Hasil yang diperoleh yaitu optimalisasi penggunaan frekuensi dan peningkatan throughput sebesar $94,87 \%$.

Pada penelitian ini dilakukan perencanaan inter-band carrier aggregation pada jaringan heterogen LTE (inter-site) dengan menggunakan skema CADS4 untuk menggantikan temporary site COMBAT yang telah dibongkar. Pada penelitian ini menggunakan layanan operator-T dengan konfigurasi macro cell sebagai primary cell (PCell) pada band-1 $2100 \mathrm{MHz}$ dan micro cell sebagi secondry cell (SCell) pada band-3 $1800 \mathrm{MHz}$. Perencanaan dilakukan berdasarkan pendekatan coverage planning dan capacity planning (Wardhana, 2014) dengan parameter-parameter yang diukur yaitu throughput, RSRP, SINR dan user connected. Berdasarkan hasil walk test yang telah dilakukan didapat nilai good coverage RSRP sebesar $75,7 \%$, good quality sebesar 53,58\% dan good throughput sebesar 48,12\%. Dari hasil perencanaan ini diharapkan dapat memenuhi target sesuai standar RF Parameter LTE dengan nilai rata-rata RSRP sebesar > $-95 \mathrm{dBm}$ SINR sebesar > $10 \mathrm{~dB}$ serta nilai throughput sebesar $>8$ Mbps dengan persentase user connected > 90\% (Putra, 2017).

\section{METODOLOGI PENELITIAN}

\subsection{Heterogeneous Network}

Heterogeneous Network (HetNet) adalah sebuah jaringan yang terdiri dari macro cell yang bertransmisi pada level daya yang tinggi, di mana macro cell melapisi small cell, yang bisa dikenal dengan Low Power Node (LPN). LPN bisa berupa pico cell, femto cell, Remote Radio Head (RRH), dan relay node (Joud, 2013). Gambar 1 merupakan ilustrasi dari HetNet.

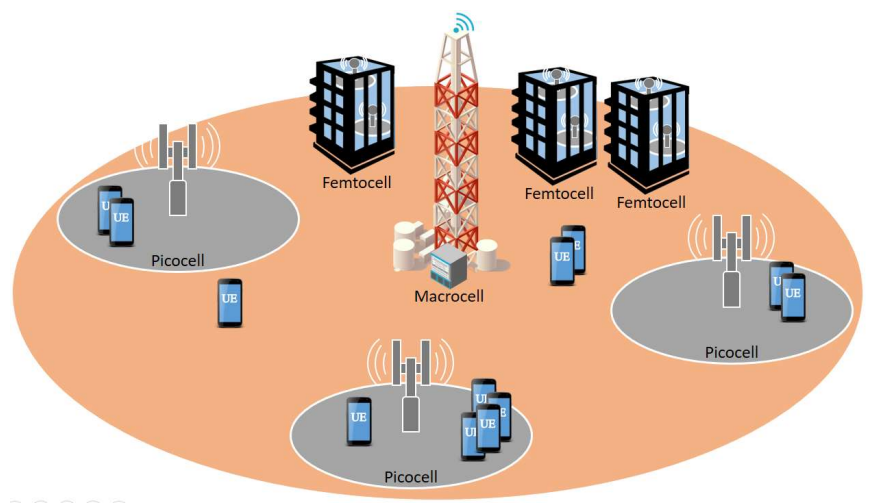

Gambar 1. Heterogeneous Network

Penggunaan small cell tersebut akan membantu macro cell untuk memberikan coverage di area outdoor tertentu maupun indoor yang lebih baik dan juga dapat meningkatkan kinerja 
yang baik untuk user di sel tepi. Sementara macro cel/ biasanya ditempatkan sebagai jaringan utama yang melapisi small cell(Grande, 2013).

\subsection{Pendekatan Perencanaan Heterogeneous Network}

Pada perencanaan jaringan heterogen ini dilakukan 2 metode pendekatan perhitungan yaitu coverage dan capacity. Pendekatan perhitungan coverage berfungsi untuk memperkirakan jumlah site small cell yang sesuai dengan memperhatikan luas wilayah coverage yang dibutuhkan, sedangkan pendekatan perhitungan capacity berfungsi untuk mengetahui jumlah site small cell yang berkaitan dengan kapasitas site untuk melayani kebutuhan potensial user sesuai perkiraan.

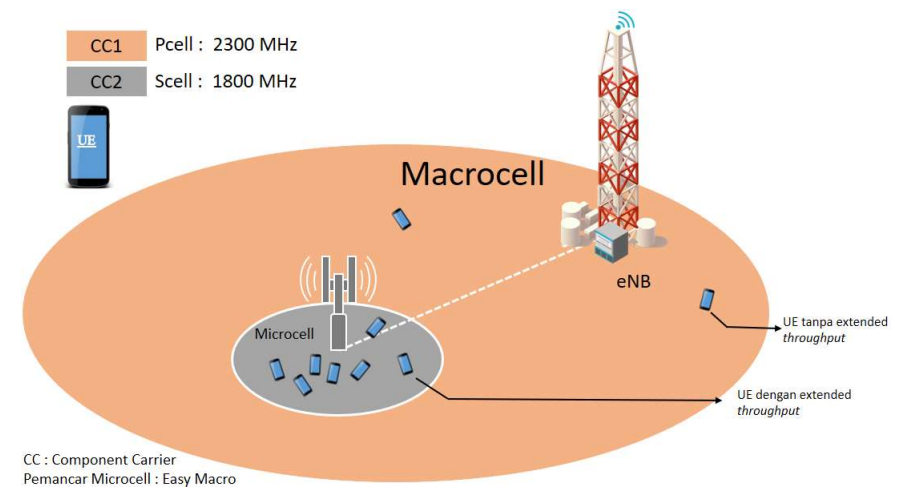

Gambar 2. Perencanaan LTE - Advanced menggunakan CADS4

Untuk mengetahui peningkatan performansi jaringan LTE - Advanced dilakukan dengan membandingkan hasil simulasi sebelum perencanaan (non-carrier aggregation) dan setelah perencanaan dilakukan. Gambar 2 adalah ilustrasi penerapan carrier aggregation pada jaringan $L T E$ - Advanced menggunakan skema CADS4. Agregasi dengan menggunakan banyak carrier akan menambah jumlah bandwidth yang dipakai, termasuk juga trunking gain dari dynamically scheduling traffic di seluruh spektrum yang digunakan. Hal ini akan meningkatkan kapasitas sel, efisiensi jaringan dan memperkaya user experience (Q Technologie, 2016).

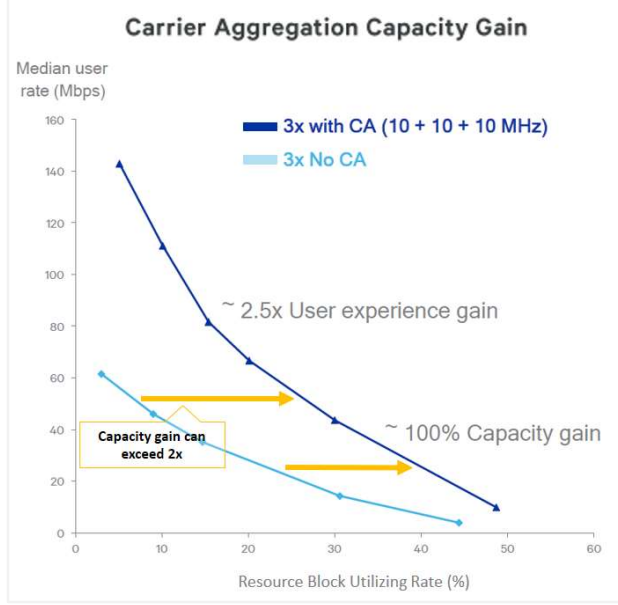

Gambar 3. Capacity Gain of Carrier Aggregation

Pada penelitian ini digunakan konfigurasi macro cell sebagai Primary Cell (PCell) pada band$12100 \mathrm{MHz}$ dan micro cell sebagai Secondry Cell (SCell) pada band-3 1800 MHz. Gambar 4 
merupakan diagram alir perencanaan yang dilakukan pada penelitian ini. Adapun untuk rincinya disajikan pada sub bab 2.3 sampai 3.5 .

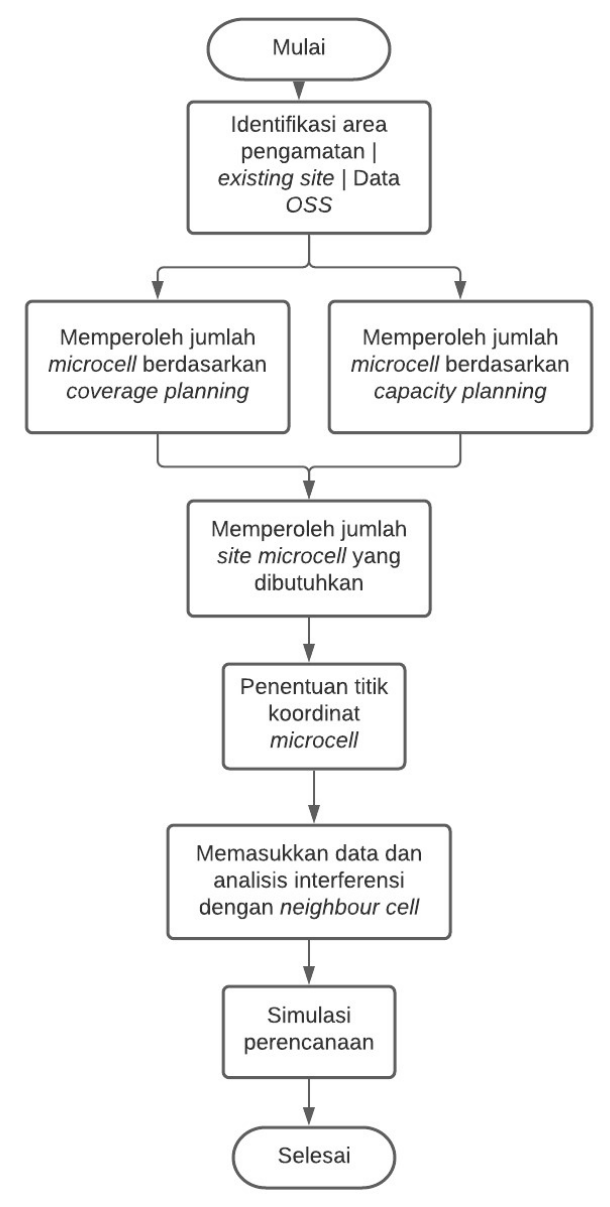

Gambar 4. Diagram Alir Perencanaan

\subsection{Identifikasi Area Pengamatan}

Objek wisata Great Asia Afria merupakan kawasan yang berada di pinggir tebing sisi jalan dengan kontur dataran mencekung. Kondisi geografisnya diperlihatkan pada Gambar 5.

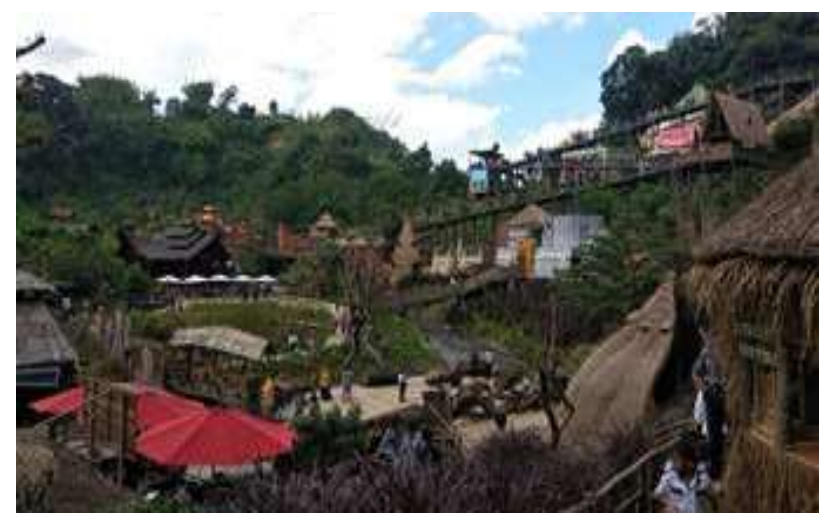

Gambar 5. Kondisi Geografis GAA 
Kondisi daerah seperti ini merupakan contour issue yang dapat mempengaruhi kualitas sinyal jaringan karena user hanya dicakup oleh site yang mengarah tepat area tersebut saja, karena kemungkinan sinyal yang dipancarkan oleh site lain akan terhalang akibat area yang terlalu landai. Tabel 1 merupakan hasil walktest di mana parameter yang digunakan untuk pengambilan sample jaringan LTE adalah RSRP, SINR dan Throughput.

Tabel 1. Hasil Reporting Walktest

\begin{tabular}{|c|c|c|c|}
\hline Parameter & Kategori & Nilai & Persentase \\
\hline \multirow{6}{*}{$\begin{array}{l}\text { Signal Level } \\
\text { /RSRP (dBm) }\end{array}$} & Sangat Baik & $\geq-80$ & $0,69 \%$ \\
\hline & Baik & $-95 \leq$ RSRP $<-80$ & $26,98 \%$ \\
\hline & Cukup Baik & $-105 \leq$ RSRP $<-95$ & $47,82 \%$ \\
\hline & Cukup Buruk & $-110 \leq$ RSRP $<-105$ & $16,51 \%$ \\
\hline & Buruk & $<-110$ & $7,79 \%$ \\
\hline & Total Good Coverage & Coverage RSRP > = -105 & $75,70 \%$ \\
\hline \multirow{6}{*}{$\begin{array}{l}\text { Signal Quality } \\
\text { /SINR (dB) }\end{array}$} & Sangat Baik & $\geq 20$ & $0,10 \%$ \\
\hline & Baik & $10 \leq \operatorname{SINR}<20$ & $8,74 \%$ \\
\hline & Cukup Baik & $0 \leq \mathrm{SINR}<10$ & $44,73 \%$ \\
\hline & Cukup Buruk & $-5 \leq$ SINR $<0$ & $42,44 \%$ \\
\hline & Buruk & $<-5$ & $3,98 \%$ \\
\hline & Total Good Quality & Quality SINR > = 0 & $53,58 \%$ \\
\hline \multirow{6}{*}{$\begin{array}{c}\text { Throughput } \\
\text { (Mbps) }\end{array}$} & Sangat Baik & Throughput $>=5$ & $26,29 \%$ \\
\hline & Baik & $3<=$ Throughput $<5$ & $8,85 \%$ \\
\hline & Cukup Baik & $1<=$ Throughput $<3$ & $12,98 \%$ \\
\hline & Cukup Buruk & $0.500<=$ Throughput $<1$ & $11,45 \%$ \\
\hline & Buruk & $0.500<$ Throughput & $40,43 \%$ \\
\hline & Total Good Throughput & Throughput $>=1$ & $48,12 \%$ \\
\hline
\end{tabular}

\subsection{Identifikasi Existing Site}

Data Existing site dapat diperoleh dari data engineering parameter penyedia jasa jaringan seluler atau operator yang berisi kumpulan informasi mengenai identitas site, di antaranya seperti site name, longitude, latitude, azimuth, tilting, dan antenna height. Dalam perencanaan jaringan $L T E$ - Advanced ini, melibatkan beberapa existing site yang berada di sekitar objek wisata Great Asia Afrika. Gambar 6 dan Tabel 2 menunjukkan letak existing site di sekitar Great Asia Afrika.

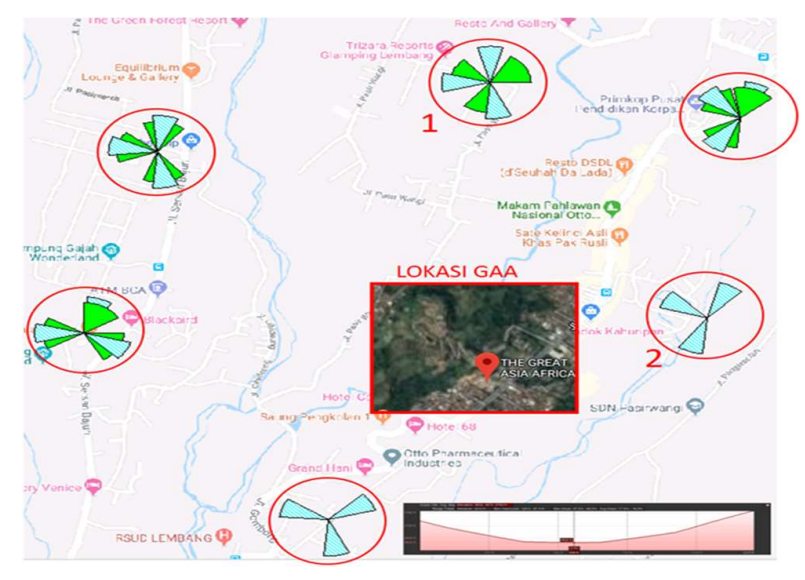

Gambar 6. Map Lokasi Existing Site 
Perencanaan LTE-A untuk Heterogeneous Network dengan Metode CADS4 di Grand Asia Afrika

Tabel 2. Data Lokasi Existing Site

\begin{tabular}{|l|c|c|c|}
\hline \multicolumn{5}{|c|}{ Existing site } \\
\hline Site id & Site name & Longitude & Latitude \\
\hline 247227 & Pasirwangi & 107,60423 & $-6,82378$ \\
\hline 242102 & Kampunggajah & 107,59487 & $-6,83153$ \\
\hline 242172 & Cihideunggudang & 107,60050 & $-6,83731$ \\
\hline 242191 & Jlpasirseret & 107,59657 & $-6,82592$ \\
\hline 242161 & Kpbatureog & 107,60998 & $-6,82487$ \\
\hline 242095 & Gudangkahuripan & 107,60921 & $-6,83105$ \\
\hline
\end{tabular}

\subsection{Identifikasi Data Operating Support System (OSS)}

Berdasarkan data OSS diperoleh pertentase Physical Resource Block (PRB) tertinggi pada periode pengamatan 19 Desember 2019 sampai 09 Januari 2020 adalah sebesar 98,3\%, sedangkan jumlah usertertinggi pada periode pengamatan yang sama yaitu sebesar 537 user. Gambar 7 dan 8 merupakan grafik PRB dan total number of user.

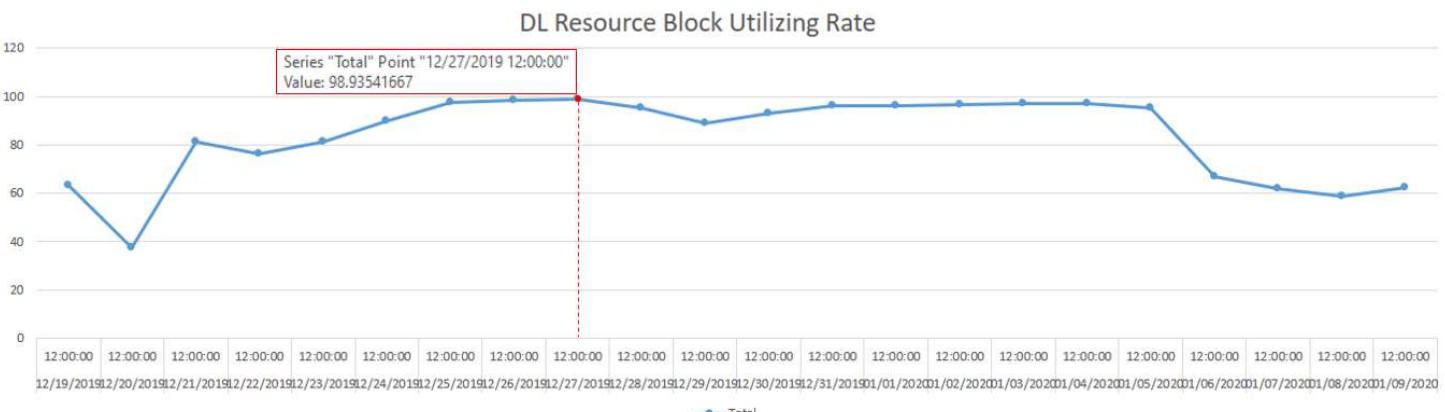

Gambar 7. PRB Sektor 2 Site Pasirwangi

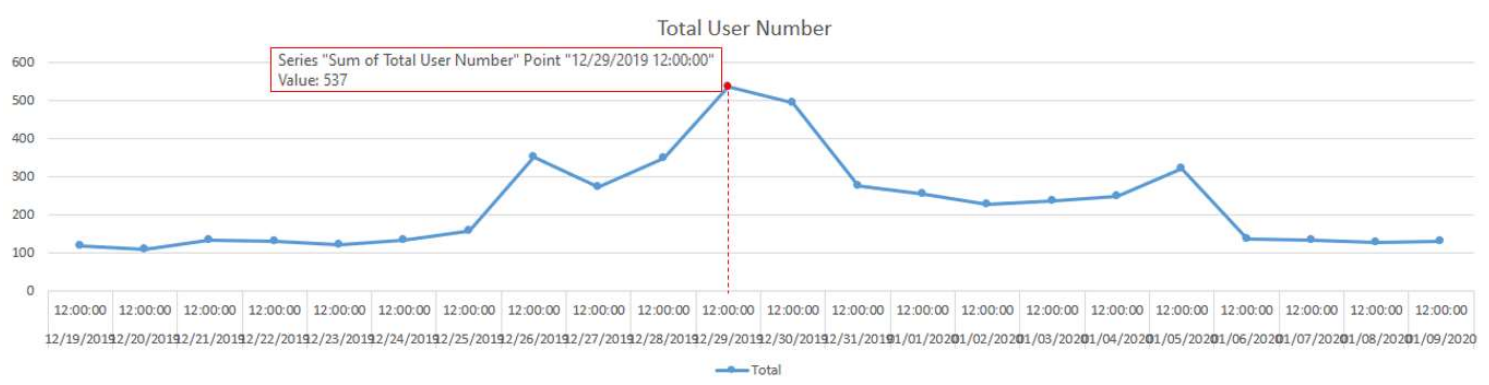

Gambar 8. Number of User Sektor 2 Site Pasirwangi

Terjadi over capacity pada sektor tersebut karena persentase PRB adalah 98,9\% dan termasuk dalam kategori critical. Pada kondisi ini meskipun banyak user masih bisa dilayani, namun throughput per user akan mengalami penurunan sehingga dapat mempengaruhi persepsi user terhadap user experience yang ditawarkan operator seluler.

\subsection{Coverage Planning}

Coverage planning pada dasarnya bertujuan untuk mendapatkan jumlah site berdasarkan luas daerah dan luas site (Putri, 2019) (Usman, 2012). Tabel 3 adalah parameter masukan yang digunakan pada perhitungan. 
Tabel 3. Parameter Masukan

\begin{tabular}{|c|c|c|}
\hline Input & Uplink & Downlink \\
\hline Data Type Channel & $\begin{array}{c}\text { Physical Uplink Shared } \\
\text { Channel (PUSCH) }\end{array}$ & $\begin{array}{c}\text { Physical Downlink Shared } \\
\text { Channel(PDSCH) }\end{array}$ \\
\hline Duplex mode & TDD \\
\hline Frequency & \multicolumn{2}{|c|}{$1800 \mathrm{MHz}$} \\
\hline System Bandwidth (MHz) & 10 \\
\hline Tx Power DL $(d B m)$ & 37 \\
\hline Tx Power UL $(d B m)$ & 23 \\
\hline Antenna Heigh $(m)$ & 10 \\
\hline MIMO Scheme & $2 \times 2$ \\
\hline
\end{tabular}

Pada pendekatan ini dilakukan tiga perhitungan antara lain Maximum Allowable Pathloss (MAPL) menggunakan model propagasi COST-231, radius sel, dan cell coverage (Putri, 2019). Perhitungan MAPL menggunakan Persamaan (1).

$$
\begin{gathered}
\text { MAPL }=46,3+33,9(\log f)-13,82 \log h_{b}-a\left(h_{m}\right)+ \\
\left(44,9-6,55 \log h_{b}\right) \log d-\operatorname{Cm} a\left(h_{m}\right)
\end{gathered}
$$

Faktor koreksi antena mobile station untuk area Urban adalah seperti pada Persamaan (2).

$$
a(h m)=(1,1 \log f-0,7) h m-(1,56 \log f-0,8)
$$

Keterangan:

$\mathrm{f} \quad=$ frekuensi $(\mathrm{MHz})$

$\mathrm{h}_{\mathrm{b}} \quad=$ tinggi antena eNodeB $(\mathrm{m})$

$\mathrm{h}_{\mathrm{m}} \quad=$ tinggi antena MS $(\mathrm{m})$

$\mathrm{a}\left(\mathrm{h}_{\mathrm{m}}\right)=$ faktor koreksi antena mobile station $(\mathrm{m})$

$\mathrm{C}_{\mathrm{m}} \quad=$ faktor jenis-jenis daerah

$\mathrm{C}_{\mathrm{m}}$ untuk kota besar $\quad=3$

$\mathrm{C}_{\mathrm{m}}$ untuk kota medium $\quad=0$

$\mathrm{C}_{\mathrm{m}}$ untuk area sub urban $\quad=-2\left(\log f(28)^{2}-5.4\right.$

$C_{m}$ untuk area rural $\quad=-4,8(\log (f))^{2}+18,3 \log (f)-40,4$

Langkah selanjutnya yaitu perhitungan radius sel menggunakan Persamaan (3) dan (4).

$$
P_{L}=46,33+33,9 \log \left(h_{b}\right)-a\left(h_{m}\right)+\left[44,9-6,55 \log \left(h_{b}\right) \log d\right.
$$

Keterangan:

$$
\begin{array}{ll}
\mathrm{P}_{\mathrm{L}} & =\text { Pathloss }(\mathrm{dB}) \\
\mathrm{h}_{\mathrm{b}} & =\text { tinggi eNode } \mathrm{B}(\mathrm{m}) \\
\mathrm{a}\left(\mathrm{h}_{\mathrm{m}}\right) & =\text { faktor koreksi antena UE } \\
\mathrm{d} & =\text { radius }(\mathrm{km})
\end{array}
$$

$$
a\left(h_{m}\right) \text { urban }=(1,1 \log f-0,7) h_{m}-(1,56 \log f-0,8)
$$


Keterangan:

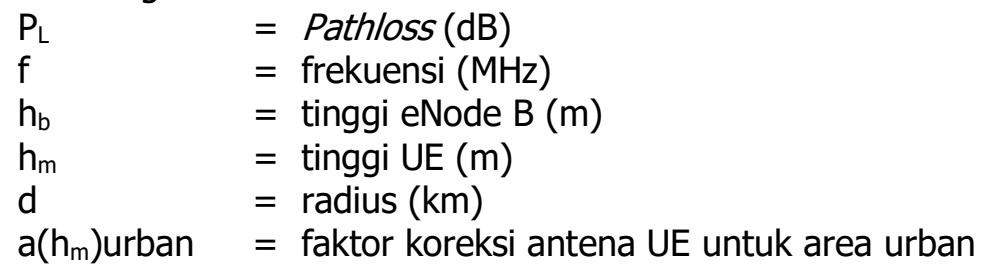

Setelah mendapatkan radius sel, selanjutnya dilakukan perhitungan cell coverage untuk sektorisasi trisectoral menggunakan Persamaan (5).

$$
\text { Luas cakupan sel }=1,95 \times d^{2}
$$

Tabel 4. Hasil Perhitungan Coverage Planning

\begin{tabular}{|c|c|c|c|c|}
\hline \multirow{2}{*}{ Parameter } & \multirow{2}{*}{ Variabel } & \multirow{2}{*}{ Unit } & \multicolumn{2}{|c|}{ Nilai } \\
\cline { 3 - 5 } & & & Uplink & Downlink \\
\hline Frekuensi & $\mathrm{f}$ & $\mathrm{MHz}$ & \multicolumn{2}{|c|}{1800} \\
\hline Tinggi antena BS & $\mathrm{h}_{\mathrm{b}}$ & $\mathrm{m}$ & \multicolumn{2}{|c|}{1,5} \\
\hline Tinggi antena MS & $\mathrm{h}_{\mathrm{m}}$ & $\mathrm{m}$ & 131,637 & 168,609 \\
\hline MAPL & $\mathrm{PL}$ & $\mathrm{dBm}$ & 0 & 0 \\
\hline Faktor koreksi daya & $\mathrm{C}_{\mathrm{m}}$ & $\mathrm{km}$ & 0,51 & 0,427 \\
\hline Radius sel & $\mathrm{d}$ & $\mathrm{km}^{2}$ & 0,681 & 0,473 \\
\hline Luas coverage sel & Cell coverage & Site & 0,74 & 1,07 \\
\hline Jumlah site & Number of Site & &
\end{tabular}

Pada Tabel 4 diketahui bahwa luas coverage sel untuk frekuensi $1800 \mathrm{MHz}$ adalah $0,681 \mathrm{~km}^{2}$ untuk downlink dan 0,473 km² untuk uplink. Jumlah site adalah 1 site untuk uplink dan 2 site untuk downlink (karena dilakukan pembulatan ke atas sesuai kaidah planning).

\subsection{Capacity Planning}

Perhitungan berdasarkan pendekatan capacity planning ini dilakukan untuk memperoleh jumlah site yang dapat menggunakan CA berdasarkan jumlah user yang berada di wilayah perencanaan (Putri, 2019) (Usman, 2012). Perhitungan forecasting number of users dilakukan dengan menggunakan Persamaan (6).

$$
\text { Future population }=P_{0}[(1+G F)] n
$$

$\mathrm{P}_{0}=$ Current population $; \mathrm{GF}=$ Grow factor $; \mathrm{N}=$ Number of forecasting years

Untuk mengetahui nilai Single User Throughput (SUT) dilakukan perhitungan menggunakan Persamaan (7).

$$
\begin{gathered}
\left(\left[\sum(\text { Throughput } / \text { Session }) \times \text { BHSA } \times \text { Penetration Ratio } \times(1+\right.\right. \\
\text { Peak to average ratio })]) / 3600
\end{gathered}
$$

BHSA $(\mathrm{h})=$ Busy Hour Service Attempt $;$ Penetration ratio $=$ How good services can affect costumers

Langkah selanjutnya dilakukan perhitungan kebutuhan trafik pada jaringan atau network throughput menggunakan Persamaan (8) dan (9). 


$$
\begin{gathered}
\text { Network Throughput }(\text { Uplink })=\text { Total user } x \text { SUTuplink } \\
\text { Network Throughput }(\text { Downlink })=\text { Total user } x \text { SUTdownlink }
\end{gathered}
$$

Untuk memperoleh nilai site capacity menggunakan Persamaan (10) dan (11).

$$
\begin{aligned}
& \text { Site Capacity }(\text { Downlink })=\text { Cell average throughput downlink } \times 3 \\
& \text { Site Capacity }(\text { Uplink })=\text { Cell average throughput uplink } \times 3
\end{aligned}
$$

Pada saat perencanaan, banyaknya jumlah site yang dibutuhkan pada suatu daerah perencanaan harus diketahui. Jumlah site diperoleh dengan menggunakan Persamaan (12).

$$
\text { Number of Site }=(\text { Network Throughput }) /(\text { Site Capacity })
$$

Tabel 5 menunjukkan hasil perhitungan berdasarkan pendekatan Capacity Planning.

Tabel 5. Hasil Perhitungan Capacity Planning

\begin{tabular}{|c|c|c|c|}
\hline \multirow{2}{*}{ Parameter } & \multirow{2}{*}{ Unit } & \multicolumn{2}{|c|}{ Nilai } \\
\cline { 3 - 4 } & & Uplink & Downlink \\
\hline Perkiraan jumlah user & Jiwa & \multicolumn{2}{|c|}{305} \\
\hline Single user throughput & Kbps & 98,718 & 372,706 \\
\hline Network throughput & Mbps & 30,149 & 113,828 \\
\hline Cell capacity & Mbps & 44,12445 & 36,77037 \\
\hline Site capacity & Mbps & 132,373 & 110,311 \\
\hline Number of site & - & 1 & 2 \\
\hline
\end{tabular}

\section{HASIL DAN PEMBAHASAN}

\begin{tabular}{|c|c|c|c|c|c|c|c|c|c|c|}
\hline \multicolumn{11}{|l|}{ 即国 } \\
\hline Transmitter & Antenna & $\begin{array}{l}\text { Height } \\
\text { (m) }\end{array}$ & $\begin{array}{c}\text { Azimuth } \\
\left({ }^{\circ}\right)\end{array}$ & $\begin{array}{c}\text { Mechanical } \\
\text { Downtilt } \\
\left({ }^{\circ}\right)\end{array}$ & $\begin{array}{c}\text { Number } \\
\text { of } \\
\text { Transmission } \\
\text { Antenna } \\
\text { Ports }\end{array}$ & $\begin{array}{c}\text { Number } \\
\text { of } \\
\text { Reception } \\
\text { Antenna } \\
\text { Ports }\end{array}$ & Transmitter Equipment & TMA Equipment & $\begin{array}{c}\text { Transmission } \\
\text { Feeder } \\
\text { Length } \\
\text { (m) }\end{array}$ & $\begin{array}{l}\text { Reception } \\
\text { Feeder } \\
\text { Length } \\
(\mathrm{m})\end{array}$ \\
\hline CIHIDEUNGGUDANG_1 & ADU451816v01_1 & 28 & 60 & & 02 & 2 & Default eNode-B Equipme & Default TMA Equipme & 34 & 34 \\
\hline CIHIDEUNGGUDANG_2 & ADU451816v01_4 & 28 & 170 & & 02 & 2 & Default eNode-B Equipme & Default TMA Equipme & 34 & 34 \\
\hline CIHIDEUNGGUDANG_3 & ADU451816v01_3 & 28 & 290 & & 02 & 2 & Default eNode-B Equipme & Default TMA Equipme & 34 & 34 \\
\hline GUDANGKAHURIPAN_ & HBX-6516DS-VTM & 29 & 30 & & 02 & 2 & Default eNode-B Equipme & Default TMA Equipme & 43 & 43 \\
\hline GUDANGKAHURIPAN_ & HBX-6516DS-VTM & 29 & 200 & & 22 & 2 & Default eNode-B Equipme & Default TMA Equipme & 43 & 43 \\
\hline GUDANGKAHURIPAN_ & HBX-6516DS-VTM & 29 & 300 & & 22 & 2 & Default eNode-B Equipme & Default TMA Equipme & 43 & 43 \\
\hline JLPASIRSERET_1 & APE4516R1v06 & 41 & 10 & & 32 & 2 & Default eNode-B Equipme & Default TMA Equipme & 46 & 46 \\
\hline JLPASIRSERET_2 & APE4516R1v06 & 41 & 170 & & 42 & 2 & Default eNode-B Equipme & Default TMA Equipme & 46 & 46 \\
\hline JLPASIRSERET_3 & APE4516R1v06 & 41 & 280 & & 22 & 2 & Default eNode-B Equipme & Default TMA Equipme & 46 & 46 \\
\hline KAMPUNGGAJAH_1 & Netop S-Wave U/U-65-21DV & 29 & 20 & & 22 & 2 & Default eNode-B Equipme & Default TMA Equipme & 35 & 35 \\
\hline KAMPUNGGAJAH_2 & Netop S-Wave U/U-65-21DV & 29 & 120 & & 22 & 2 & Default eNode-B Equipme & Default TMA Equipme & 35 & 35 \\
\hline KAMPUNGGAJAH_3 & Netop S-Wave U/U-65-21DV & 29 & 270 & & 22 & 2 & Default eNode-B Equipme & Default TMA Equipme & 35 & 35 \\
\hline KPBATUREOG_1 & APE4516R1v06 & 38 & 20 & & 12 & 2 & Default eNode-B Equipme & Default TMA Equipme & 43 & 43 \\
\hline KPBATUREOG_2 & APE4516R1v06 & 38 & 130 & & 52 & 2 & Default eNode-B Equipme & Default TMA Equipme & 43 & 43 \\
\hline KPBATUREOG_3 & APE4516R1v06 & 38 & 315 & & 32 & 2 & Default eNode-B Equipme & Default TMA Equipme & 43 & 43 \\
\hline PASIRWANGI_1 & AQU4518R21v06 & 38 & 0 & & 42 & 2 & Default eNode-B Equipme & Default TMA Equipme & 75 & 75 \\
\hline PASIRWANGI_2 & AQU4518R21v06 & 38 & 170 & & 42 & 2 & Default eNode-B Equipme & Default TMA Equipme & 75 & 75 \\
\hline PASIRWANGI_3 & AQU4518R21v06 & 38 & 270 & & 42 & 2 & Default eNode-B Equipme & Default TMA Equipme & 75 & 75 \\
\hline
\end{tabular}

\subsection{Peletakan Small Cell}

Proses peletakan site small cel/ ini dilakukan sebelum melakukan perencanaan salah satu hal yang perlu diperhatikan adalah memperkirakan di mana lokasi yang memungkinkan untuk dilakukan pemasangan antena tanpa harus membangun tower pemancar baru.

Gambar 9. Titik Koordinat Peletakan Small Cell (by Atoll) 
Penentuan titik koordinat micro cell dilakukan dengan memodelkan peletakan site small cell menggunakan metode physical tuning dan Automatic Cell Planning (ACP) untuk mengetahui perbandingan kondisi yang sesuai dengan perencanaan di wilayah tersebut. Gambar 9 menunjukkan titik koordinar peletakan small cell. Tipe antena yang digunakan yaitu antena easy macro AAU3940. Gambar 10 menunjukkan letak pemasangan antena micro cell yang telah dirancang.
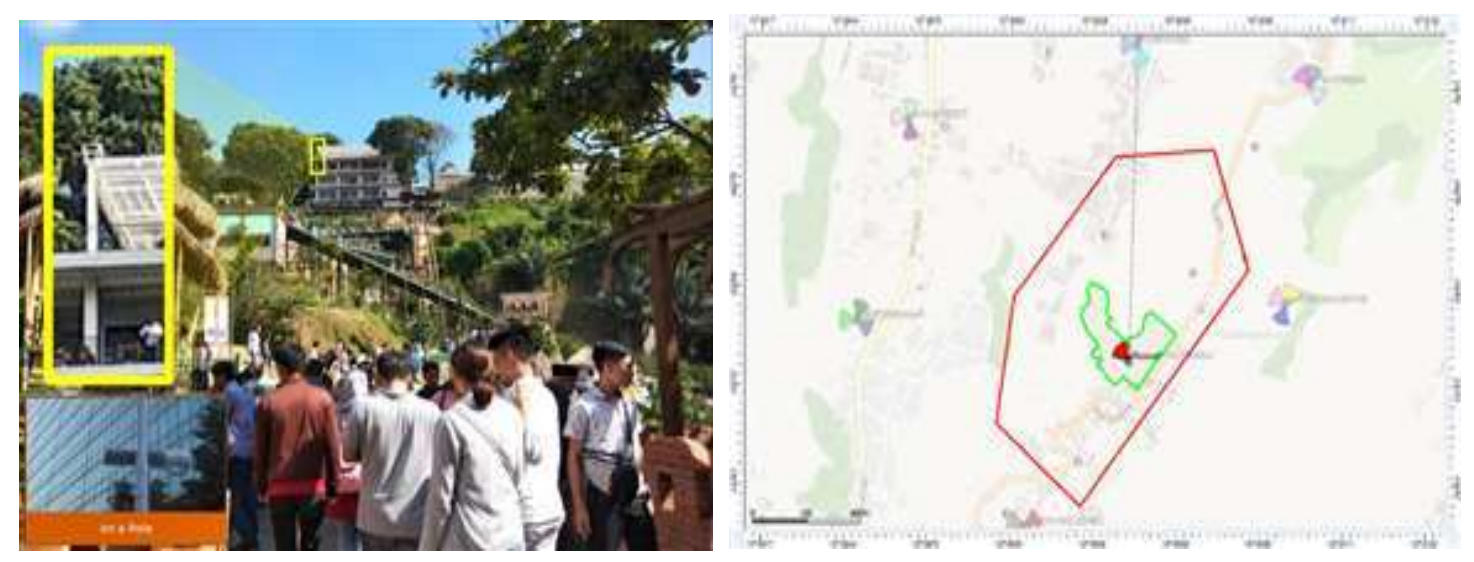

Gambar 10. Letak Pemasangan Antena Micro Cell

\subsection{Skenario Simulasi}

Setelah dilakukan proses perencanaan dan peletakan micro cell, selanjutnya adalah proses konfigurasi inter-band carrier aggregation dengan skema Carrier Aggregation Deployment Scenario 4 (CADS4). Simulasi dilakukan dengan tujuan meningkatkan performansi jaringan yaitu peningkatan kapasitas dan throughput. Simulasi perencanaan inter-band carrier aggregation pada heterogen network dengan konfigurasi macro cell sebagai Primary Cell (PCell) di band-1 $2100 \mathrm{MHz}$ dengan bandwidth $15 \mathrm{MHz}$ dan micro cell sebagai Secondry Cell (SCell) di band-3 $1800 \mathrm{MHz}$ dengan bandwidth $10 \mathrm{MHz}$. Hasil dari skenario ini dibandingan dengan parameter RF jaringan LTE dari hasil simulasi sebelum perencanaan (non carrier aggregation) dan setelah perencanaan dilakukan (carrier aggregation).

Dalam melakukan simulasi parameter RSRP dan SINR akan dibatasi pada dua area kalkulasi yaitu computation zone dan focus zone. Sedangkan untuk parameter throughput dan user connected dibagi menjadi dua skenario yaitu:

1. Dilakukan simulasi initial dan final dalam kondisi full traffic untuk mengetahui peningkatan kapasitas jaringan secara keseluruhan sekaligus membuktikan efek capacity gain akibat penggunaan fitur carrier aggregation.

2. Dilakukan simulasi initial dan final dalam kondisi full traffic, $1 / 2$ traffic dan $1 / 4$ traffic untuk membuktikan adanya extended throughput yang didapatkan user akibat penerapan fitur carrier aggregation.

\subsection{Hasil Simulasi RSRP dan SINR}

Pada Tabel 6 berikut ini ditunjukkan hasil simulasi coverage untuk throughput konfigurasi CA_40A-3A yang diterima oleh user pada area pengamatan. 
Tabel 6. Perbandingan RSRP dan SINR

\begin{tabular}{|c|c|c|c|c|c|c|}
\hline \multirow[b]{2}{*}{ Parameter } & \multirow[b]{2}{*}{ Kategori } & \multirow[b]{2}{*}{ Nilai } & \multicolumn{2}{|c|}{ Initial } & \multicolumn{2}{|c|}{ Final } \\
\hline & & & $\begin{array}{l}\text { Comp } \\
\text { zones }\end{array}$ & $\begin{array}{l}\text { Focus } \\
\text { zones }\end{array}$ & $\begin{array}{l}\text { Comp } \\
\text { zones }\end{array}$ & $\begin{array}{l}\text { Focus } \\
\text { zones }\end{array}$ \\
\hline \multirow{6}{*}{$\begin{array}{l}\text { RSRP } \\
(\mathrm{dBm})\end{array}$} & $\begin{array}{c}\text { Sangat } \\
\text { Baik }\end{array}$ & $\geq-80$ & $0 \%$ & $0 \%$ & $3 \%$ & $3 \%$ \\
\hline & Baik & $\begin{array}{c}-90 \leq \text { RSRP }< \\
-80\end{array}$ & $0 \%$ & $0 \%$ & $33 \%$ & $33 \%$ \\
\hline & $\begin{array}{l}\text { Cukup } \\
\text { Baik }\end{array}$ & $\begin{array}{c}-100 \leq \text { RSRP } \\
<-90\end{array}$ & $66,54 \%$ & $66,54 \%$ & $52,95 \%$ & $52,95 \%$ \\
\hline & $\begin{array}{l}\text { Cukup } \\
\text { Buruk }\end{array}$ & $\begin{array}{c}-110 \leq \text { RSRP } \\
<-100\end{array}$ & $7,06 \%$ & $7,06 \%$ & $5,82 \%$ & $5,82 \%$ \\
\hline & Buruk & $<-110$ & $26,40 \%$ & $26,40 \%$ & $4,72 \%$ & $4,72 \%$ \\
\hline & \multicolumn{2}{|c|}{ Rata-Rata RSRP (dBm) } & $-96,41$ & $-103,63$ & $-95,21$ & $-92,65$ \\
\hline \multirow{6}{*}{ SINR (dB) } & $\begin{array}{l}\text { Sangat } \\
\text { Baik }\end{array}$ & $\geq 25$ & $27,11 \%$ & $27,11 \%$ & $21,42 \%$ & $21,42 \%$ \\
\hline & Baik & $\begin{array}{c}15 \leq \text { SINR }< \\
25\end{array}$ & $38,00 \%$ & $38,00 \%$ & $32,64 \%$ & $32,64 \%$ \\
\hline & $\begin{array}{l}\text { Cukup } \\
\text { Baik }\end{array}$ & $\begin{array}{c}10 \leq \operatorname{SINR}_{15}< \\
\end{array}$ & $10,45 \%$ & $10,45 \%$ & $19,92 \%$ & $19,92 \%$ \\
\hline & $\begin{array}{l}\text { Cukup } \\
\text { Buruk }\end{array}$ & $5 \leq \operatorname{SINR}<10$ & $4,91 \%$ & $4,91 \%$ & $12,59 \%$ & $12,59 \%$ \\
\hline & Buruk & $<5$ & $19,53 \%$ & $19,53 \%$ & $13,43 \%$ & $13,43 \%$ \\
\hline & \multicolumn{2}{|c|}{ Rata-Rata SINR (dB) } & 19,75 & 16,49 & 19,26 & 16,55 \\
\hline
\end{tabular}

Berdasarkan hasil simulasi RSRP initial, pada focus zone diperoleh hasil $26,40 \%$ cakupan berada pada rentang $<-110 \mathrm{dBm}$ (buruk), 7,06\% cakupan berada pada rentang $\geq-110$ hingga $-100 \mathrm{dBm}$ (cukup buruk), 66,54\% cakupan berada pada rentang $\geq-100$ hingga $-90 \mathrm{dBm}$ (cukup baik), $0 \%$ wilayah cakupan terletak pada rentang $\geq-90$ hingga $-80 \mathrm{dBm}$ (baik) dan sebesar $0 \%$ wilayah cakupan berada pada rentang $\geq-80 \mathrm{dBm}$ (sangat baik). Nilai rata-rata yang diperoleh dari hasil simulasi prediksi RSRP pada jaringan heretogen $L T E$-Advanced tersebut adalah sebesar $-103,63 \mathrm{dBm}$. Berdasarkan hasil simulasi RSRP final, pada focus zone diperoleh hasil $0,15 \%$ cakupan berada pada rentang $<-110 \mathrm{dBm}$ (buruk), 5,82\% cakupan berada pada rentang $\geq-110$ hingga $-100 \mathrm{dBm}$ (cukup buruk), 52,95\% cakupan berada pada rentang $\geq-100$ hingga $-90 \mathrm{dBm}$ (cukup baik), 33\% wilayah cakupan terletak pada rentang $\geq-90$ hingga -80 $\mathrm{dBm}$ (baik) dan sebesar 3\% wilayah cakupan berada pada rentang $\geq-80 \mathrm{dBm}$ (sangat baik). Nilai rata-rata yang diperoleh dari hasil simulasi prediksi RSRP pada jaringan heretogen $L T E-$ Advanced tersebut adalah sebesar $-92,65 \mathrm{dBm}$. Berdasarkan hasil simulasi SINR initial, pada focus zone diperoleh hasil 19,53\% cakupan berada pada rentang $<5 \mathrm{~dB}$ (buruk), 4,91\% cakupan berada pada rentang $\geq 5$ hingga $10 \mathrm{~dB}$ (cukup buruk), 10,45\% cakupan berada pada rentang $\geq 10$ hingga $15 \mathrm{~dB}$ (cukup baik), 38\% wilayah cakupan terletak pada rentang $\geq 15$ hingga $25 \mathrm{~dB}$ (baik) dan sebesar $27,11 \%$ wilayah cakupan berada pada rentang $\geq 25 \mathrm{~dB}$ (sangat baik). Nilai rata-rata yang diperoleh dari hasil simulasi prediksi SINR pada jaringan heretogen LTE-Advanced tersebut adalah sebesar 16,49 dB. Berdasarkan hasil simulasi SINR final, pada focus zone diperoleh hasil $13,43 \%$ cakupan berada pada rentang $<5 \mathrm{~dB}$ (buruk), $12,59 \%$ cakupan berada pada rentang $\geq 5$ hingga $10 \mathrm{~dB}$ (cukup buruk), 19,92\% cakupan berada pada rentang $\geq 10$ hingga $15 \mathrm{~dB}$ (cukup baik), 32\% wilayah cakupan terletak pada rentang $\geq 15$ hingga $25 \mathrm{~dB}$ (baik) dan sebesar $21 \%$ wilayah cakupan berada pada rentang $\geq 25$ $\mathrm{dB}$ (sangat baik). Nilai rata-rata yang diperoleh dari hasil simulasi prediksi SINR pada jaringan heretogen $L T E$-Advanced tersebut adalah sebesar 16,55 dB. 


\subsection{Hasil Simulasi Parameter Throughput dan User Connected}

Pada tahap ini dilakukan simulasi sebelum dan setelah menerapkan skema CADS4. Proses simulasi dilakukan pada boundary area focus zone dengan menggunakan beberapa service parameter di antaranya VoIP, Video Phone, Video Converence, Real Time Gaming, Streaming Media, IMS Signalling, Web Browsing, File Transfer, Email dan P2P File Sharing. Dari beberapa service parameter tersebut diambil satu layanan yang paling banyak penggunaannya berdasarkan akumulasi throughput layanan tersebut. Hasil dari layanan tersebut kemudian dijadikan load conditions pada software Atoll untuk mengetahui prediksi actual throughput yang diperoleh user. Pada Tabel 7 ditunjukkan perbandingan nilai throughput dan user connected sebelum dan setelah menerapkan CADS4 dimana kedua simulasi tersebut menggunakan konfigurasi kondisi full traffic.

Tabel 7. Perbandingan Throughput dan User Connected

\begin{tabular}{|c|c|c|c|c|c|c|}
\hline \multirow{2}{*}{ Parameter } & \multicolumn{3}{|c|}{ Inital } & \multirow{2}{*}{\multicolumn{2}{|c|}{$\begin{array}{l}\text { Final } \\
\text { Value }\end{array}$}} & \multirow{2}{*}{ Unit } \\
\hline & \multicolumn{2}{|c|}{ Value } & Unit & & & \\
\hline Total User & \multicolumn{2}{|c|}{306} & $100 \%$ & \multicolumn{2}{|c|}{291} & $100 \%$ \\
\hline User Connected & \multicolumn{2}{|c|}{217} & $70 \%$ & \multicolumn{2}{|c|}{283} & $97 \%$ \\
\hline User Rejected & \multicolumn{2}{|c|}{89} & $29,10 \%$ & \multicolumn{2}{|c|}{8} & $2,70 \%$ \\
\hline $\begin{array}{l}\text { Throughput Demand } \\
\text { (Mbps) }\end{array}$ & UL 159,29 & DL 15,48 & Mbps & UL 159,78 & $\mathrm{DL} 15,2$ & Mbps \\
\hline $\begin{array}{l}\text { Effective hroughput } \\
\text { (Mbps) }\end{array}$ & UL 23,01 & DL 7,94 & Mbps & UL 104,74 & DL 12,64 & Mbps \\
\hline Top Service & \multicolumn{2}{|c|}{ streaming media } & - & \multicolumn{2}{|c|}{ streaming media } & - \\
\hline $\begin{array}{l}\text { Service throughput } \\
\text { (Mbps) }\end{array}$ & UL 23 & DL 1,87 & Mbps & DL 74 & UL 6,02 & Mbps \\
\hline User on Service & \multicolumn{2}{|c|}{23} & User & \multicolumn{2}{|c|}{74} & User \\
\hline $\begin{array}{c}\text { Actual throughput } \\
\text { per User }\end{array}$ & \multicolumn{2}{|c|}{1,3} & Mbps & \multicolumn{2}{|c|}{1,06} & Mbps \\
\hline
\end{tabular}

Persentase user connected sebelum perencanaan adalah sebesar $70 \%$ dari 306 user, sedangkan setelah perencanaan adalah sebesar 97\% dari 291 user. Hal ini menunjukkan konektivitas user yang dihasilkan dari simulasi $L T E$ - Advanced telah memenuhi target yang ingin dicapai. Pada hasil simulasi sebelum perencanaan, user yang memperoleh service streaming media dengan rata-rata throughput sebesar 1,3 Mbps dengan 23 user saja. Sedangkan pada hasil simulasi setelah perencanaan, user yang memperoleh rata-rata throughput sebesar 1,06 Mbps sebanyak 74 user. Hal ini menunjukkan peningkatan kapasitas sebesar tiga kali lipat dibandingkan sebelum perencanaan.

\subsection{Hasil Simulasi Parameter Throughput Full Traffic, Half Traffic dan 1/4 Traffic}

Pada tahap ini dilakukan kalkulasi simulasi berdasarkan tiga kondisi yang berbeda yaitu konfigurasi dengan kondisi ketika trafik penuh (full traffic), $50 \%$ tafik (half traffic) dan $25 \%$ trafik (1/4 traffic). Simulasi dilakukan di focus zone area dengan service yang digunakan sebagai perbandingan yaitu Streaming Media. Proses simulasi ini dilakukan untuk membuktikan konsep capacity gain sesuai dengan grafik pada Gambar 2 yang menunjukan penurunan throughput per user seiring bertambahnya kapasitas trafik begitu pula sebaliknya. Perbandingan hasil simulasi berdasarkan kondisi trafik ditunjukan pada Tabel 8. 
Ariyanto, dkk

Tabel 8. Perbandingan Throughput Full Traffic, Half Traffic dan $1 / 4$ Traffic

\begin{tabular}{|c|c|c|c|c|c|c|c|}
\hline & \multicolumn{3}{|c|}{ INITIAL } & \multicolumn{3}{|c|}{ FINAL } \\
\hline & & \multicolumn{2}{|c|}{ value } & \multirow{2}{*}{$\begin{array}{l}\text { unit } \\
\text { Mbps }\end{array}$} & \multicolumn{2}{|c|}{ value } & unit \\
\hline \multirow{3}{*}{$\begin{array}{c}\text { Full } \\
\text { traffic }\end{array}$} & $\begin{array}{l}\text { Service Troughput } \\
\text { (Mbps) }\end{array}$ & DL 23 & UL 1,87 & & DL 74 & UL 6,02 & Mbps \\
\hline & User on Service & \multicolumn{2}{|c|}{23} & User & \multicolumn{2}{|c|}{74} & User \\
\hline & $\begin{array}{c}\text { Actual Troughput } \\
\text { per User }\end{array}$ & \multicolumn{2}{|c|}{1,3} & Mbps & \multicolumn{2}{|c|}{1,6} & Mbps \\
\hline \multirow{3}{*}{$\begin{array}{c}\text { Half } \\
\text { traffic }\end{array}$} & $\begin{array}{c}\text { Service Troughput } \\
\text { (Mbps) }\end{array}$ & DL 30 & UL 2,44 & Mbps & DL 77,54 & UL 4,15 & Mbps \\
\hline & User on Service & \multicolumn{2}{|c|}{30} & User & \multicolumn{2}{|c|}{51} & User \\
\hline & $\begin{array}{l}\text { Actual Troughput } \\
\text { per User }\end{array}$ & \multicolumn{2}{|c|}{1,2} & Mbps & \multicolumn{2}{|c|}{1,5} & Mbps \\
\hline \multirow{3}{*}{$\begin{array}{c}1 / 4 \\
\text { traffic }\end{array}$} & $\begin{array}{l}\text { Service Troughput } \\
\text { (Mbps) }\end{array}$ & DL 35 & UL 2,85 & Mbps & DL 69,42 & UL 2,77 & Mbps \\
\hline & User on Service & \multicolumn{2}{|c|}{35} & User & \multicolumn{2}{|c|}{34} & User \\
\hline & $\begin{array}{c}\text { Actual Troughput } \\
\text { per User }\end{array}$ & \multicolumn{2}{|c|}{1,57} & Mbps & \multicolumn{2}{|c|}{2,03} & Mbps \\
\hline
\end{tabular}

Semakin rendah kepadatan trafik, throughput per-user yang didapatkan semakin meningkat di mana peningkatan throughput pada simulasi setelah perencanaan jaringan $\angle T E$ - Advanced tampak lebih konsisten dengan jumlah useryang dilayani lebih banyak dibandingkan sebelum perencanaan. Pada konfigurasi kondisi $1 / 4$ traffic atau $25 \%$ dari full traffic, jumlah user yang dilayani kurang lebih sama akan tetapi throughput yang didapatkan pada simulasi setelah perencanaan jaringan $L T E$ - Advanced sedikit lebih tinggi dari pada sebelum perencanaan. Hal ini kemungkin terjadi akibat adanya extended throughput yang disebabkan dual-connectivity yang diperoleh UE dari sel macro dan micro.

\section{KESIMPULAN}

Pada area focus zone, sebelum menggunakan skema CADS4 nilai RSRP dengan kategori good coverage adalah 66,54\%, dengan rata-rata sebesar $-103,3 \mathrm{dBm}$. Sedangkan setelah menggunakan skema CADS4, nilai RSRP dengan kategori good coverage sebesar 89\% dengan nilai rata-rata RSRP sebesar $-92 \mathrm{dBm}$. Sebelum menggunakan skema CADS4 nilai SINR dengan kategori good quality adalah 75,55\%, dengan rata-rata sebesar $16,49 \mathrm{~dB}$. Sedangkan setelah menggunakan skema CADS4, nilai SINR dengan kategori good quality sebesar 73,98\% dengan nilai rata-rata SINR sebesar 16,55 dB. Hasil tersebut mengindikasikan bahwa kualitas jaringan setelah perencanaan di objek wisata Great Asia Afrika (GAA) telah memenuhi standar provider yaitu rata-rata RSRP $>-95 \mathrm{dBm}$ dan SINR $>10 \mathrm{~dB}$. Berdasarkan hasil simulasi sebelum perencanaan diperoleh persentase user connected hanya sebesar $70 \%$ dari 306 user sedangkan setelah perencanaan sebesar 97\% dari 291 user. Hal ini menunjukkan konektivitas user yang dihasilkan dari simulasi $L T E$ - Advanced telah memenuhi standar provider. Pada hasil simulasi sebelum perencanaan, user yang memperoleh service streaming media dengan rata-rata throughput sebesar 1,3 Mbps dengan 23 user. Sedangkan pada hasil simulasi setelah perencanaan, user yang memperoleh rata-rata throughput sebesar 1,06 Mbps sebanyak 74 user. Hal ini menunjukkan peningkatan kapasitas sebesar tiga kali lipat dibandingkan sebelum perencanaan. 
Perencanaan LTE-A untuk Heterogeneous Network dengan Metode CADS4 di Grand Asia Afrika

\section{DAFTAR RUJUKAN}

Agustina, A. (2019). Telkomsel Jabar jamin jaringan sinyal tak "lelet" saat tahun baruan. Retrieved from Merdeka.com website: https://m.merdeka.com/bandung/halobandung/telkomsel-jabar-jamin-jaringan-sinyal-tak-akan-lelet-saat-akhir161225g.html

Diansyah, D. (2019). Analisis Perencanaan Jaringan LTE Advanced Menggunakan Metode Tri - Band Carrier Aggregation di Soreang Kabupaten Bandung. Telkom University.

Faz. (2019). Telkomsel: Layanan Streaming Bakal Meningkat Saat Natal dan Tahun Baru. Retrieved from Merdeka.com website: https://www.merdeka.com/teknologi/telkomsellayanan-streaming-bakal-meningkat-saat-natal-dan-tahun-baru.html

Geraldine, D. (2019). Perencanaan Jaringan LTE- Advanced Menggunakan Metode Inter-Band Carrier Aggregation Di Kota Karawang. Telkom University.

Grande, D. (2013). Performance Analysis of QoS in LTE - Advanced Heterogeneous Networks. Joud, D. (2013). Pico Cell Range Expansion toward LTE-Advanced Wireless Heterogeneous Networks.

Kusuma, Fadli, D. (2019). Analisis Penerapan Metode Inter Band Carrier Aggregation Pada Jaringan LTE-Advanced Untuk Meningkatkan Capacity User Di Daerah Bandung Tengah. Telkom University.

Mubarok, A. (2019). Analisis Dampak Inter-Band Carrier Aggregation pada Perencanaan Jaringan LTE-Advanced. ELKOMIKA: Jurnal Teknik Energi Elektrik, Teknik Telekomunikasi, \& Teknik Elektronika, 72 (2).

Putra, D. (2017). 4G LTE Advanced for Beginner \& Consultant. Bandung: Prandia Self Publishing.

Putri, H. (2019). Pengukuran dan Perencanaan Sistem Komunikasi Seluler. Yogyakarta: Graha Ilmu.

Putri, H. (2021). Optimalisasi Penggunaan Frekuensi dan Peningkatan Throughput pada Jaringan LTE-A menggunakan Metode CADS2. ELKOMIKA: Jurnal Teknik Energi Elektrik, Teknik Telekomunikasi, \& Teknik Elektronika, 9(1).

Q. Technologie. (2016). Delivering on the LTE Advanced promise.

Usman, U. (2012). Fundamental Teknologi Seluler LTE. Bandung: Rekayasa Edition.

Wang, H., Rosa, C., \& I. P. (2013). Dedicated Carrier Deployment in Heterogeneous Networks with Inter-site Carrier Aggregation.IEEE. https://doi.org/10.1109/WCNC.2013.6554658

Wardhana, L. (2014). 4G Handbook Edisi Bahasa Indonesia. nulisbuku.com. 